\title{
Preliminary Phytochemical Screening and Assessment of Pharmacological Activities of Leaves and Stems of Gynura procumbens (Lour.) Merr.
}

\author{
Tuz Mia Nur Akhi ${ }^{1}$, Mohiminul Adib ${ }^{2}$, Quazi Sufia Islam ${ }^{2}$, Irin Sultana ${ }^{1}$, \\ Rafiqul Haider $^{3}$ and Muhammad Ibrahim ${ }^{1}$ \\ ${ }^{1}$ Department of Pharmacy, Southern University of Bangladesh, Mehedibag, Chittagong, Bangladesh \\ ${ }^{2}$ Department of Pharmaceutical Chemistry, Faculty of Pharmacy, University of Dhaka \\ Dhaka-1000, Bangladesh \\ ${ }^{3}$ Minor Forest Products Division, Bangladesh Forest Research Institute, Chittagong, Bangladesh
}

Received: October 27, 2018; Accepted: November 10, 2018; Published: January 17, 2019)

\begin{abstract}
The present study was designed to evaluate the preliminary phytochemical profiles and pharmmacological activities of different extractives (methanol and chloroform) of the leaves and stems of Gynura procumbens (Lour.) Merr. Preliminary phytochemical screenings demonstrated the presence of alkaloids, glycosides, steroids, flavonoids, tannins, saponins, gums and amides and reducing sugar in leaves and stems. Significant $\alpha$-amylase inhibitory activities were found by the methanol (66.67\%) and chloroform (70.63\%) extracts of leaves of $G$. procumbens as compared to the standard drug acarbose (95.45\%) at a concentration of $400 \mu \mathrm{g} / \mathrm{ml}$. In the castor oil-induced diarrhea, the maximum inhibition of defecation was found by the chloroform fraction. During the anxiolytic activity test which was performed by open field and hole cross method, different extractives of leaves and stems of $G$. procumbens $(500 \mathrm{mg} / \mathrm{kg}$ bw) reduced the total count of square crossed and hole crossed to a considerable extent in comparison to the control groups. In antipyretic assay, both extracts reduced the temperature to a significant extent in comparison to the standard group.
\end{abstract}

Key words: Gynura procumbens, anxiolytic, $\alpha$-amylase, Brewer's yeast-induced pyrexia.

\section{Introduction}

Traditional knowledge of medicinal plants and their use by indigenous healers and drug development are not only useful for conservation of cultural tradition and biodiversity but also for community health care and drug development in the local people (Mesfin et al., 2013). In the western world, as the people are becoming aware of the side effect of synthetic drugs, there is an increasing interest in the natural product remedies (Verma et al., 2008). Bangladesh being a subtropical country is a good repository of plants. There are around 5,000 angiosperms distributed among 200 families. Approximately, 500 of these are being used in the traditional medicines for the treatment of different types of diseases (Kaisa et al., 2011).
Gynura procumbens commonly known as longevity spinach is one of those precious medicinal herbs of Asterceae that is popular due to its traditional medicinal properties (Mou et al., 2016). It is used in the treatment of various ailments such as eruptive fevers, rash, diabetes, constipation, hypertension and urinary tract infection (Keng et al., 2009; Perry et al., 1980). This plant is indigenous to Malaysia, Indonesia and Thailand and Myanmar (Wiart, 2002). However, this is not a native plant of Bangladesh, but it is being cultivated in different are as in the name of 'Diabetic leaves'. This is a small plant in which the stems are fleshy and the leaves are ovate-elliptic or lanceolate. This tropical herbaceous medicinal plant is highly branched with hairy green leaves that are alternately arranged on hairy purple stem. It produces purple tubular bisexual flowers

Correspondence to: Muhammad Ibrahim; Email: mdibrahim_sub@yahoo.com; Mobile number: +8801622401098. 
(Rahman et al., 2013). Numerous studies have exposed that various extracts of $G$. procumbens leaves contain several active chemical constituents such as flavonoids, saponins, tannins, terpenoids and sterol glycosides (Akowuah et al., 2002; Kaewseejan et al., 2012; Zahra et al., 2011). Previous studies also reported that the extracts of the leaves contained rutin, kaempferol and two potential antioxidant components which are kaempferol-3-O-rutinoside and astragalin (Yam et al., 2008).

The present study was conducted with the leaves and stems of G. procumbens growing in Bangladesh to evaluate the antidiabetic, antidiarrheal, anxiolytic and antipyretic activities.

\section{Materials and Methods}

Chemicals and reagents: All chemicals and solvents used in this study were of analytical grade and purchased from Merck, Germany. Standard drugs such as acarbose, glibenclamide, azithromycin, loperamide, acetyl salicylic acid (ASA), paracetamol, and diazepam were obtained from several pharmaceuticals of Bangladesh where alpha-amylase were obtained from Diastase, Loba Chemic Pvt. Ltd., India

Collection of plant materials and extraction: $G$. procumbens was collected from Bangladesh Forest Research Institute (BFRI), Chittagong. Taxonomical identification of this plant was made by the experts of Bangladesh Forest Research Institute (BFRI) Herbarium, Chittagong where voucher specimens have been maintained for future reference.

Preparation of plant material: The collected plant materials were washed with running tap water and then were dried at a temperature not exceeding $40^{\circ} \mathrm{C}$ in an oven. The dry materials were ground to a coarse powder with the help of a grinding machine and kept in an airtight container until extraction was commenced. The powdered materials ( $250 \mathrm{~g}$ leaves and $212 \mathrm{~g}$ stems) were separately extracted with 800 $\mathrm{ml}$ of methanol followed by chloroform in a Soxhlet apparatus (Quickfit, England). The extracts were separately concentrated with a rotary evaporator (Heidolph, Germany) under reduced temperature and pressure to provide gummy residues designated as hot methanolic crude extracts. These produced methanol extract of the leaves (MELGP) (3.414 g), chloroform extract of leaves (CELGP) (4.26 g), methanol extract of the stems (MESGP) (2.301 g) and chloroform extract of the stems (CESGP) (6.67 g) of G. procumbens.

Experimental animals: Young Swiss-albino mice, average weight $18-30 \mathrm{~g}$ of either sex, 4-5 weeks of age, were purchased from Animal Research Branch of the Bangladesh Council of Scientific and Industrial Research (BCSIR), Chittagong, Bangladesh. The mice were maintained under standard laboratory conditions (Zimmermann, 1983) with temperature $\left(27.0 \pm 1.0^{\circ} \mathrm{C}\right)$, relative humidity (55-65\%) and $12 \mathrm{hr}$ light/12 hr dark cycle and fed with icddr,bformulated rodent food and water $(\mathrm{ad}$ libitum).

Preliminary phytochemical investigations: The crude methanol extracts of the leaves and the stems of $G$. procumbens were subjected to various tests (Table 1) to determine the chemical nature of the extracts (Evans et al., 2002; Hossan et al., 2013)

Evaluation of antidiabetic activity by $\alpha$-amylase assay: The $\alpha$-amylase inhibitory activity was measured using the starch-iodine method (Komaki et al., 2003). Briefly, $80 \mu \mathrm{l}$ of $\alpha$-amylase solution ( 0.050 $\mathrm{mg} / \mathrm{ml}$ ) was mixed with $5.2 \mathrm{ml}$ of Tris- $\mathrm{HCl}$ buffer $(0.01 \mathrm{M}$ containing $0.006 \mathrm{M} \mathrm{NaCl}, \mathrm{pH} 6.8)$ and $320 \mu \mathrm{l}$ of different fraction of extracts of leaves and stems of G. procumbens. After incubation at $37^{\circ} \mathrm{C}$ for $20 \mathrm{~min}$, $400 \mu \mathrm{l}$ of starch solution $(0.1 \%)$ was added and the mixture re-incubated at $37^{\circ} \mathrm{C}$ for $20 \mathrm{~min}$, after which $8 \mathrm{ml}$ of $0.01 \%$ acidic iodine solution was added. Samples of each test tube were filtered and the absorbance measured at $578 \mathrm{~nm}$. Inhibition of amylase activity was compared with stardardacarbose activity. The percentage inhibition was calculated by comparing to the control which did not have the extracts. Inhibition of enzyme activity was calculated as:

$(\%)=\left(\mathrm{Abs}_{\text {sample }}-\mathrm{Abs}_{\text {control }}\right) \times 100 /\left(\mathrm{Abs}_{\text {blank }}-\mathrm{Abs}_{\text {control }}\right)$ where, $\quad \mathrm{Abs}_{\text {sample }}=$ absorbance of sample (extract/standard), $\mathrm{Abs}_{\text {Blank }}=$ absorbance of blank (no 
sample \& starch), and $\mathrm{Abs}_{\text {control }}=$ absorbance of control (no sample)

Screening for antidiarrheal activity: Antidiarrheal activity of different extractives of leaves and stems was investigated by castor oilinduced-diarrhea (Shoba et al., 2001). The animals were divided into control, standard and three test groups containing three mice. Control group received vehicle (1\% Tween-80 in double distilled water) at the doses of $10 \mathrm{ml} / \mathrm{kg}$ body weight (orally). The standard group received loperamide at the doses of 3 $\mathrm{mg} / \mathrm{kg}$ (orally); test groups received the fractionated methanolic and chloroform extracts of leaves and stems of G. procumbens at the dose of $500 \mathrm{mg} / \mathrm{kg}$ of body weight orally. Then the latency period and diarrheic secretion were counted for 4 hours using standard protocol (Shoba et al., 2001).

Test for anxiolytic activity: The anxiolytic activity of the plant extractives was examined by using the open field test and hole cross test. The animals were divided in to four groups, with each group consisting of three mice. First group received normal saline, second group received diazepam (1 $\mathrm{mg} / \mathrm{kg} \mathrm{bw}$ ) and the remaining groups received plant extract $(500 \mathrm{mg} / \mathrm{kg} \mathrm{bw})$.

Open field test. The open field area was made of plain wood and consisted of a square area $(45 \mathrm{~cm} \times$ $45 \mathrm{~cm} \times 20 \mathrm{~cm})$. The floor had a square sheet of wood $(45 \mathrm{~cm} \times 45 \mathrm{~cm})$ with the surface divided into sixteen small squares. Leaves and stems of different extractives of G. procumbens at the dose $500 \mathrm{mg} / \mathrm{kg}$ bw (orally), double distilled water (DDW) $10 \mathrm{ml} / \mathrm{kg}$ bwand standard diazepam $5 \mathrm{mg} / \mathrm{kg} \quad$ (i.p.) wereadministered to the experimental animals. 15 minutes later, the number of square crossed by the mice was counted for 5 minutes. Then the samples data were compared with normal and standard group for possible action of different extractives. Number of square crossed was calculated manually and converted to the final result (Kishore et al., 2012)

Hole cross test. The hole cross test (HCT), described by Takagi (Takegi et al., 1971) was performed after slight modification of the previously proposed method. The aim of this study was to characterize the emotional behavior of mice using the hole-board test. 15 minutes later, the mice were allowed to move through the hole. The number of hole crossed by the mice was counted for 5 minutes. The mice were allowed to move through the hole into both the chambers and the samples data were compared with normal and standard.

Antipyretic activity: This study was conducted by slightly modifying the method described by Adams et al. (1968). Animals of either sex were divided into 4 groups containing 3 in each group for this experiment. The antipyretic activities of extract were evaluated using Brewer's yeast induced pyrexia (Naveed et al., 2012) in Swiss albino mice. Different extractives of leaves and stems of $G$. procumbens were administered orally at a dose of $500 \mathrm{mg} / \mathrm{kg}$ bw. Rectal temperature was recorded by digital thermometer at $0,1,2$ and 3 hrs after drug administration and tabulated in the table 5 .

Statistical analysis: Results were expressed as the mean \pm SEM where $\mathrm{p}$ values $(\mathrm{p}<0.05)$ were considered as statistically significant.

\section{Results and Discussion}

The phytochemical screenings of the methanol and chloroform extractives of G. procumbens (Lour.) Merr. revealed the occurrence of various bioactive secondary metabolites (Table 1).

In case of $\alpha$-amylase activity, table 2 demonstrated the \% inhibitory activity of the different extractives. Highest activity was shown by chloroform extract of the leaves of G. procumbens.

During antidiarrheal test, the methanol and chloroform extracts of stems of G. procumbens shown 63.79 and $68.96 \%$ inhibition of defecation respectively in comparison with the standard drug loperamide which was $72.41 \%$. (Table 3)

In case of evaluation of anxiolytic activity by hole cross test, the plant extracts showed significant increase in the number of line crossing when compared to standard (diazepam) and control (double distilled water) as shown (Table 4). In the open field test, administration of plant extracts in mice exhibited substantial increase in number of 
squares crossed in comparison to standard and control (Table 4). Although pharmacotherapeutic approaches for the management of anxiety disorders include psychotropic drugs, these agents are limited by their side-effect profile, the need for dietary precautions, and drug interactions (Baldessarini, 1990). These are some of the factors that caused interest in many researchers to evaluate new compounds from plant origin in the hope to identify other anxiolytic drugs with fewer unwanted side effects. There is ample evidence that interaction between plant extracts with serotonergic pathway could be responsible for such anxiolytic action (Unis et al., 1997)

Table 1. Preliminary phytochemical analysis of the methanol and chloroform extractives of leaves and stems of $G$. procumbens.

\begin{tabular}{|c|c|c|c|c|c|c|c|c|c|}
\hline Chemical groups & Alkaloids & Glycosides & Steroids & Tannins & Flavonoids & Saponins & Reducing sugar & Gums & Amides \\
\hline $\begin{array}{l}\text { Methanol extract } \\
\text { (leaves) }\end{array}$ & ++++ & + & + & ++ & + & + & - & - & + \\
\hline $\begin{array}{l}\text { Chloroform extract } \\
\text { (leaves) }\end{array}$ & +++ & + & + & + & + & + & - & + & + \\
\hline $\begin{array}{l}\text { Methanol extract } \\
\text { (stems) }\end{array}$ & ++ & + & + & + & + & + & - & - & + \\
\hline $\begin{array}{l}\text { Chloroform extract } \\
\text { (stems) }\end{array}$ & + & ++++ & ++ & ++ & - & + & + & + & + \\
\hline
\end{tabular}

Table 2. Inhibition of amylase activity by standard and different extractives of leaves of G. procumbens.

\begin{tabular}{lc}
\hline $\begin{array}{l}\text { Treatment groups } \\
(400 \mu \mathrm{g} / \mathrm{ml})\end{array}$ & \% Inhibition \\
\hline Standard (Acarbose) & 95.45 \\
MESGP & 60 \\
CESGP & 30.62 \\
MELGP & 66.67 \\
CELGP & 70.63 \\
\hline
\end{tabular}

Table 3. \% Inhibition of defecation of the different extractives of leaves and the stems of G. procumbens.

\begin{tabular}{lll}
\hline Treatment groups & \% Defecation & \% Inhibition of defecation \\
\hline Control (DDW) $10 \mathrm{ml} / \mathrm{kg}$ & 100 & 0.00 \\
Standard (Loperamide) $3 \mathrm{mg} / \mathrm{kg}$ & 27.59 & 72.41 \\
MELGP $(500 \mathrm{mg} / \mathrm{kg})$ & 41.39 & 58.61 \\
CELGP $(500 \mathrm{mg} / \mathrm{kg})$ & 41.39 & 58.61 \\
MESGP $(500 \mathrm{mg} / \mathrm{kg})$ & 36.21 & 63.79 \\
CESGP $(500 \mathrm{mg} / \mathrm{kg})$ & 31.04 & 68.96 \\
\hline
\end{tabular}


Table 4. Effect of different extractives of the leaves and the stems of G. procumbens on the holecrossed and open field test in mice

\begin{tabular}{lcc}
\hline \multirow{2}{*}{ Clinical groups } & Hole cross test & Open field test \\
\cline { 2 - 3 } Control (DDW) & Mean no of hole crossed \pm SEM & Mean no of field crossed \pm SEM \\
Standard (Diazepam) & $10 \pm 1.00$ & $90 \pm 2.00$ \\
MELGP & $3.67 \pm 0.58^{*}$ & $49 \pm 4.58^{*}$ \\
CELGP & $5.33 \pm 1.53^{*}$ & $74.67 \pm 2.52^{*}$ \\
MESGP & $6 \pm 2.00^{*}$ & $81.33 \pm 3.06^{*}$ \\
CEGGP & $4.33 \pm 0.58^{*}$ & $69.33 \pm 4.04^{*}$ \\
\hline
\end{tabular}

SEM = standard error of mean, values were expressed as mean \pm SEM $(n=3), *$ Statistically significant in comparison to baseline data where $\mathrm{p}<0.05$ when compared to control.

Table 5. Effect of different extractives of leaves and stems of G. procumbens in Brewer's yeast-induced pyrexia in mice.

\begin{tabular}{lccccc}
\hline \multirow{2}{*}{$\begin{array}{l}\text { Treatment groups \& doses } \\
(\mathrm{mg} / \mathrm{kg})\end{array}$} & \multicolumn{5}{c}{ Rectal temperature in ${ }^{\circ} \mathrm{F}$ after $18 \mathrm{hrs}$ of yeast injection } \\
\cline { 2 - 6 } & $-18 \mathrm{hrs}$ & $0 \mathrm{hrs}$ & $1 \mathrm{hrs}$ & $2 \mathrm{hrs}$ & $3 \mathrm{hrs}$ \\
\hline Control (DDW) $10 \mathrm{ml} / \mathrm{kg}$ & $97.63 \pm 0.35$ & $101.43 \pm 0.21$ & $101.17 \pm 0.32$ & $101.03 \pm 0.38$ & $100.90 \pm 0.44$ \\
Standard (paracetamol) & $97.67 \pm 0.12^{*}$ & $101.68 \pm 0.20$ & $98.80 \pm 0.26^{*}$ & $98.27 \pm 0.47^{*}$ & $97.23 \pm 0.15^{*}$ \\
$150 \mathrm{mg} / \mathrm{kg}$ & & & & \\
MELGP (500 mg/kg) & $98.30 \pm 0.53^{*}$ & $100.90 \pm 0.62$ & $99.23 \pm 0.23^{*}$ & $98.50 \pm 0.36^{*}$ & $97.37 \pm 0.50^{*}$ \\
CELGP (500 mg/kg) & $98.34 \pm 0.58^{*}$ & $100.53 \pm 0.67$ & $99.73 \pm 0.06^{*}$ & $98.63 \pm 0.23^{*}$ & $96.47 \pm 0.29^{*}$ \\
MESGP (500 mg/kg) & $98.27 \pm 0.90^{*}$ & $101.23 \pm 0.62$ & $99.57 \pm 0.49^{*}$ & $98.30 \pm 0.20^{*}$ & $97.50 \pm 0.30^{*}$ \\
CESGP (500 mg/kg) & $98.07 \pm 0.25^{*}$ & $100.57 \pm 0.40^{*}$ & $99.53 \pm 0.25^{*}$ & $98.47 \pm 0.25^{*}$ & $97.47 \pm 0.07^{*}$ \\
\hline
\end{tabular}

SEM $=$ standard error of mean, values were expressed as mean \pm SEM $(n=3), *$ Statistically significant in comparison to baseline data where $\mathrm{p}<0.05$ when compared to control.

In case of antipyretic activity, after administering Brewer's yeast injection, the experimental mices showed an average increase of about $4^{\circ} \mathrm{F}$ to $5^{\circ} \mathrm{F}$ of rectal temperature. Extractives of $G$. procumbens leaves and stems at the doses of $500 \mathrm{mg} / \mathrm{kg}$, significantly $(\mathrm{p}<0.05)$ showed antipyretic activity starting from $1^{\text {st }}$ hour to $3^{\text {rd }}$ hours after drug administration. The methanol fraction of leaves and stems decreased temperature up to $3.53^{\circ} \mathrm{F}$ and $3.73^{\circ} \mathrm{F}$, whereas extracts of leaves and stems decrease temperature up to $3.63^{\circ} \mathrm{F}$ and $4.90^{\circ} \mathrm{F}$ and chloroform extract of leaves and stems decreased temperature up to $4.06^{\circ} \mathrm{F}$ and $3.50^{\circ} \mathrm{F}$, respectively (Table 5). The reference standard drug, paracetamol showed significant antipyretic activity starting after $1^{\text {st }}$ hour to $3^{\text {rd }}$ hours $\left(4.45^{\circ} \mathrm{F}\right)$.

\section{Conclusion}

Different extractives of the leaves and stems of G. procumbens demonstrated significant antidiabetic and antipyretic activities with a considerable amount of anxiolytic and antidiarrheal effects. The results verify some of the traditional uses of the plant. However, further research is necessary to isolate the lead compounds from this plant and their full spectrum of efficacy.

\section{Acknowledgements}

Authors wish to thank Microbiology Lab., Southern University of Bangladesh, Chittagong and Bangladesh Council of Scientific and Industrial Research (BCSIR), Centre for Advance Research in Sciences (CARS), University of Dhaka for providing instrumental facilities to carry out the experiments. 


\section{References}

Adams, S.S., Hebborn, P. and Nicholson, J.S. 1968. Some aspects of the pharmacology of ibufenac, a nonsteroidal anti-inflammatory agent. J. Pharm. Pharmacol. 20, 305-312.

Akowuah, GA., Sadikum, A. and Mariam, A. 2002. Flavonoid identification and hypoglycaemic studies of the butanol fraction from Gynura procumbens. Pharm. Biol. 40, 405-410.

Baldessarini, R.J. 1990. Drugs and the treatment of psychiatric disorders. Goodman and Gilman's The Pharmacological Basis of Therapeutics. Eighth Edition, pp. 383-435.

Bauer, A.W., Kirby, W.M.M., Sherris, J.C. and Turck, M. 1966. Antibiotic susceptibility testing by a standardized single disk method. Am. J. Clin. Pathol. 45, 493-496.

Brand-Williams, W., Cuvelier, M.E. and Berset, C.L.W.T. 1995. Use of a free radical method to evaluate antioxidant activity. LWT-Food sci. Technol. 28, 2530.

Evans, W.C. and Trease. 2002. Pharmacognosy. London: WB Saunders. pp. 32-33, 95-99, 512, 547.

Hossan, M.A., Ibrahim, M., Ahsan, M.Q., Aktar, F., Kuddus, M.R., Chowdhury, M.M.U. and Rashid, M.A. 2013. Pharmacological and phytochemical screenings of ethanol extract of Etlingera linguiformis (Roxb.) RM Sm. growing in Bangladesh. Bangladesh Pharm. J. 16, 33-37.

Kaewseejan, N., Puangpronpitag, D. and Nakornriab, M. 2012. Evaluation of phytochemical composition and antibacterial property of Gynura procumbens extract. Asian. J. Plant. Sci. 11, 1-5.

Kaisa, M.A. 2011. A review on phytochemicals from some medicinal plants of Bangladesh. J. Pharm. Pharm. Sci. 1, 87-95.

Keng, C.L., Yee, L.S. and Pin, P.L. 2009. Micropropagation of Gynura procumbens (Lour.) Merr. an important medicinal plant. J. Med. Plants Res. 3, 105111.

Kishore, R.N., Anjaneyulu, N., Ganesh, M.N. and Sravya, N. 2012. Evaluation of anxiolytic activity of ethanolic extract of Foeniculum vulgare in mice model. Int. J. Pharm. Pharm. Sci. 4, 584-586.

Komaki, E., Yamaguchi, S., Maru, I., Kinoshita, M., Kakeyi, K., Ohta, Y. and Tsukada, Y. 2003. Identification of anti-amylase components from olive leaf extracts. Food. Sci. Technol. Res. 9, 35-9.
Mesfin, K., Tekle, G. and Tesfay, T. 2013. Ethnobotanical study of traditional medicinal plants used by indigenous people of Gemad District, Northern Ethiopia. J. Med. Plants. Stud. 1, 32-37.

Mou, K.M. and Dash, P.R. 2016. A Comprehensive Review on Gynura procumbens Leaves. Int. J. Pharmacogn. 3, 167-174.

Naveed, M., Saeed, M. and Khan, H. 2012. Antipyretic, analgesic and anti-inflammatory activity of Viola betonicifolia whole plant. BMC. Complement. Alternat. Med. 12, 59.

Perry, L.M. and Metzger, J. 1980. Medicinal plants of east and southeast Asia: attributed properties and uses. MIT press. p. 622.

Rahman, A.F.M.M. and Asad, M. 2013. Chemical and biological investigations of the leaves of Gynura procumbens. Int. J. Biol. Sci. 3, 36-43.

Shoba, F.G. and Thomas, M. 2001. Study of antidiarrhoeal activity of four medicinal plants in castor oil-induced diarrhea. J. Ethnopharmacol. 76, 73-76.

Takagi, K., Watanabe, M. and Saito, H. 1971. Studies on the spontaneous movement of animals by the hole cross test: Effect of 2-dimethylaminoethane. Its acylates on the central nervous system. Jpn. J. Pharmacol. 21, 797-810.

Unis, A.S., Cook, E.H. and Vincent, J.G. 1997. Platelet serotonin measures in adolescents with conduct disorder. Biol. Psych. 42, 553-559.

Verma, S. and Singh, S.P. 2008. Current and future status of herbal medicines. Vet. World. 1, 347.

Wiart, C. 2002. Medicinal plants of Southeast Asia. Prentice Hall, ed. 2, p. 395.

Yam, M., Sadikun, A. and Asmawi, M. 2008. Antioxidant potential of Gynura procumbens. Pharm. Biol. 46, 616-25.

Zahra, A.A., Kadir, F.A., Mahmood, A.A., Suzy, S.M., Sabri, S.Z., Latif, I.I. and Ketuly, K.A. 2011. Acute toxicity study and wound healing potential of Gynura procumbens leaf extract in rats. J. Med. Plants. Res. 5, 2551-2558.

Zheng, G.D., Shuai, L.Q.W., Li, D.M. and Zhu, Y.T. 2014. Extraction and antibacterial effects of Gynura procumbens leaves. ShipinKeji. 39, p. 218-221.

Zimmermann, M. 1983. Ethical guidelines for investigations of experimental pain in conscious animals. Pain. 16, 109-110. 